\title{
Development of urban green belts - a super future for ecological balance, Gulbarga city, Karnataka
}

\author{
R. Mala Ramesh*, R. Nijagunappa \\ Department of Studies and Research in Environmental Science, Gulbarga University, \\ Gulbarga - 585 106, India \\ *E-mail address: manjunathk2007@rediffmail.com
}

\begin{abstract}
Green belt land is an open space around bigger cities. The main purpose of the green belt is to protect the land from urban sprawl, and maintain the designated area for forestry, agriculture as well as to provide habitat to wildlife. Green belt offers a number of benefits for population. Areas that are designated as green belt must not be built upon, however, that does not mean that no buildings can be erected in green belt. GREENBELT is a policy and land use designation used in land use/land cover planning. Green belt policy may not work well in all areas and has been a subject of criticism; however, its advantages by far outweigh its disadvantages. The Green belt land covers about $2 \%$ of total geographical area in Gulbarga city of Karnataka state. They do not solve the problem related to low forest cover in the Gulbarga District but they significantly improve air quality and help combat a number of environmental problems. During the data collection (43\%) of respondents both knew that Green Belts surround city, and valued Green Belts as places to enjoy quiet recreation It is confirmed that Green Belt policy has been highly effective in eco-friendship relation. Green Belts have a role to play in achieving positive land use objectives. The concept of Green Belt also has strong support amongst the general public, even if they do not always understand the full details of the planning policy. These areas could take on an even greater significance in the face of climate.
\end{abstract}

Keywords: Urban Green space; Green structure; Green belt

\section{INTRODUCTION}

The introduction of green belts was the culmination of over 50 years of environmentalist pressure with roots in the garden city movement and widespread academic interest in COMBATING URBAN SPRAWL. Green belt development is proposed "to provide a reserve supply of public open spaces and of recreational areas and to establish a green belt or girdle of open space" (Cohen, B., 2006).

As the outward growth of GULBARGA DISTRICT (A Divisional Head Quarter of Hyderabad-Karnataka Region) was seen to be firmly repressed, residents owning properties further from the built-up area also campaigned for this policy of urban restraint, partly to safeguard their own investments but often invoking an idealized scenic/rustic argument which laid the blame for most social ills upon urban influences.

The general concept of "green belt" has evolved in recent years to encompass "GREENSPACE" and "GREENSTRUCTURE", taking into account urban green space, an important aspect of SUSTAINABLE DEVELOPMENT in the 21st century. Areas that 
are designated as green belt must not be built upon because green belt is defined as an open space, however, that does not mean that no buildings can be erected in green belt. Some areas that are designated as green belt land may have lesser value in environmental sense, however, any dramatic changes of the existing green belt policy could have unforeseen consequences for all future generations.

GREENBELT is a policy and land use designation used in land use planning to retain areas of largely "Undeveloped land", "Wild Land" and "Farm Land", which surround or neighbor urban areas. In essence, a green belt is an invisible line encircling a certain area, preventing development of the area and allowing wildlife to return and be established (McMichael AJ., 2000).

\section{LOCATION AND ACCESSIBILITY}

Gulbarga also known as Kalburgi is a city in the Indian state of Karnataka. It is the administrative headquarters of Gulbarga District. It was formerly part of Nizam's Hyderabad state. Gulbarga is $200 \mathrm{~km}$ from Hyderabad and $623 \mathrm{~km}$ north of Bangalore. It is being recently renamed as Kalburgi (Meaning land of stones). Gulbarga is well connected by road (State and National Highway) and railways (Broad gauge) to Bangalore, Mumbai, Hyderabad and other major cities. The airport is under construction near village Srinivas Saradagi. Gulbarga has a 55.5-kilometre $(34.5 \mathrm{mi})$ long, four lane ring road. Aerial view of Gulbarga City is shown in (Figure 1) (http://nammagulbarga.com/ accessed 2013).

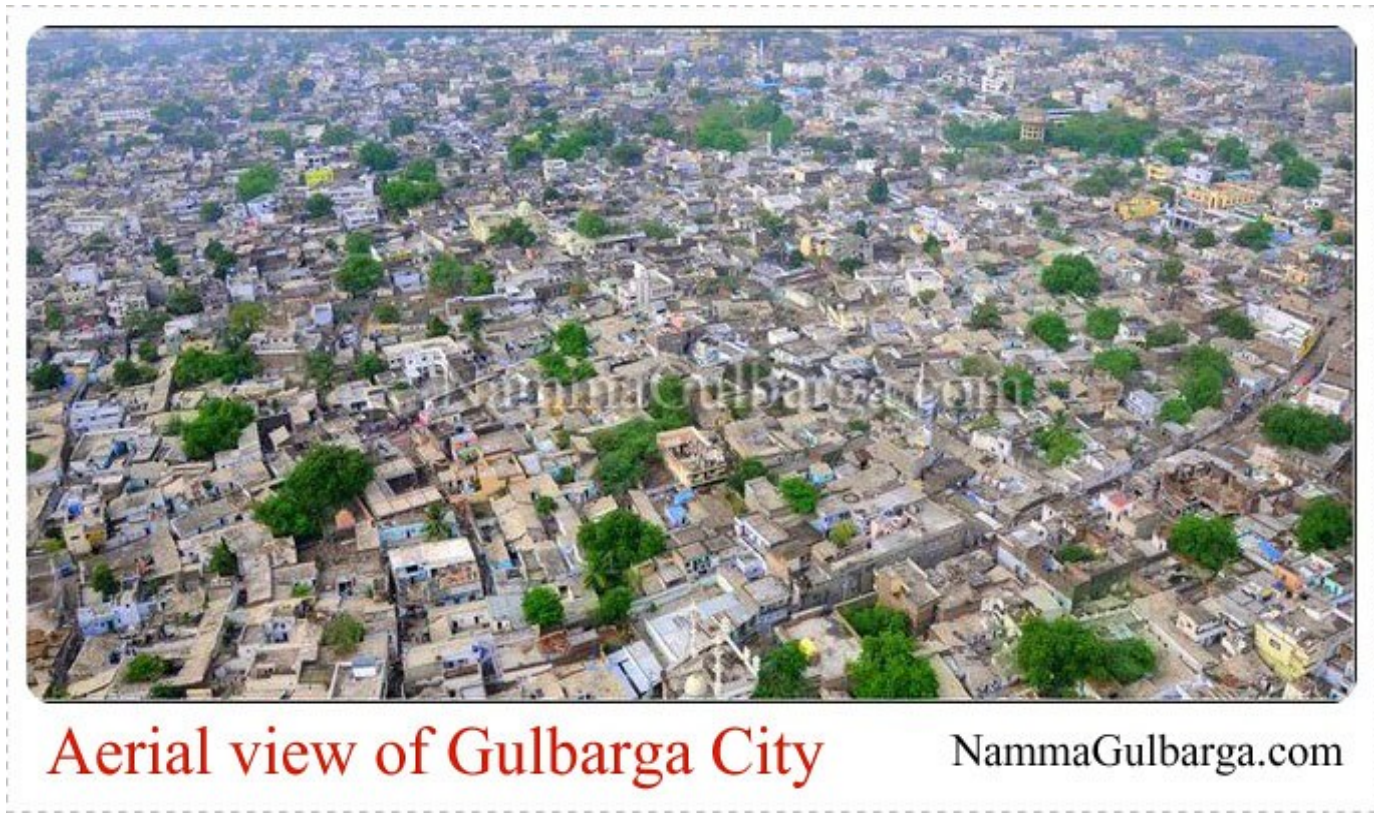

Figure 1. Panoramic view of Gulbarga city-Karnataka(India). 


\section{CLIMATE}

The weather in Gulbarga consists of three main seasons. The summer spans from late February to mid-June. It is followed by the southwest monsoon, which spans from late June to late September. It is then followed by dry winter weather until mid-January.

Temperatures during the different seasons are:

- Summer: 30 to $44^{\circ} \mathrm{C}$

- Monsoon: 23 to $32^{\circ} \mathrm{C}$

- Winter: 04 to $31^{\circ} \mathrm{C}$

Table1. Seasonal variation of climate of Gulbarga City.

\begin{tabular}{|c|c|c|c|c|c|c|c|c|c|c|c|c|c|}
\hline \multicolumn{14}{|c|}{ Climate data for Gulbarga } \\
\hline Month & Jan & Feb & Mar & Apr & May & Jun & Jul & Aug & Sep & Oct & Nov & Dec & Year \\
\hline Average high ${ }^{\circ} \mathbf{F}$ & 85.6 & 89.6 & 95 & 100.4 & 101.3 & 93.2 & 86 & 86.9 & 87.8 & 87.8 & 85.3 & 84.2 & 90.26 \\
\hline Average low ${ }^{\circ} \mathbf{F}$ & 60.4 & 63.3 & 72.1 & 76.8 & 77.7 & 75.2 & 73.2 & 72.5 & 72.7 & 70.7 & 64.8 & 59.4 & 69.9 \\
\hline Precipitation inches & 0.106 & 0.173 & 0.177 & 0.713 & 1.551 & 4.689 & 4.587 & 5.843 & 7.346 & 4.142 & 1.098 & 0.181 & 30.606 \\
\hline Average high ${ }^{\circ} \mathrm{C}$ & 29.8 & 32.0 & 38.0 & 42.0 & 43.5 & 34.0 & 30.0 & 30.5 & 31.0 & 31.0 & 29.6 & 29.0 & 32.37 \\
\hline Average low ${ }^{\circ} \mathrm{C}$ & 15.8 & 17.4 & 22.3 & 24.9 & 25.4 & 24.0 & 22.9 & 22.5 & 22.6 & 21.5 & 18.2 & 15.2 & 21.06 \\
\hline Precipitation mm & 2.7 & 4.4 & 4.5 & 18.1 & 39.4 & 119.1 & 116.5 & 148.4 & 186.6 & 105.2 & 27.9 & 4.6 & 777.4 \\
\hline
\end{tabular}

A perusal to the table! Indicates that during the summer the average temperature is very high and one cannot walk out till $6.45 \mathrm{pm}$ in the evening. There are several evidences of sunstroke to domestic lives.

\section{MERITS AND LIMITATIONS OF GREEN BELT}

\section{The objectives of green belt policy are to:}

- Protect natural or semi-NATURAL ENVIRONMENTS

- Improve AIR QUALITY within URBAN areas

- Ensure that urban dwellers have access to countryside, with consequent educational and recreational opportunities; and

- Protect the unique character of RURAL communities that might otherwise be absorbed by expanding SUBURBS.

The green belt has many advantages for people:

- Walking, camping, and biking areas close to the cities and towns

- Contiguous HABITAT network for wild PLANTS, ANIMALS and WILDLIFE

- Cleaner air and water

- Better land use of areas within the bordering cities 


\section{BENEFITS OF GREEN BELT}

The idea of a belt of land around major cities and towns that is reserved for an open space was originally proposed to halt the URBAN SPRAWL, and PROTECT THE RURAL ENVIRONMENT and HISTORIC TOWNS from URBANIZATION. However, green belt policy has been shown to have a number of benefits for both rural and urban areas as well as for the environment which has made it one of the most effective measures against the current environmental problems and nature conservation and protection issues (Moudon, AV. and Wee BV., 2009).

The main purpose of introduction of green belts - prevention of unrestricted urban sprawl has been shown very effective because all areas that are designated as green belt land are not allowed to be built upon. Some buildings are allowed in green belt such as those for agricultural purposes, while developmental projects are approved only in rare cases (Arana, M. and Garcia, A., 1998). Thus green belt land has become the key in protection of natural and semi-natural environment as well as a retreat for wildlife (PH., Zanin, FB. and Barbosa, W. A., 2002).

By checking urbanization, green belt areas helped save the rural communities from being absorbed by large urban centers as well as helped preserve unique landscape which offers many benefits to the urban population as well. Access to an open space provides a number of recreational and educational opportunities, while the physical barrier between urban areas improves air quality in urban (Li, B., Tao, S. and Dawson, R.W., 2002). In addition, the strips of lands that are kept as open space help preserve unique character of smaller historic towns because they prevent the smaller towns from becoming suburbs of larger urban centers and from merging with the neighboring towns.

At the same time, the restrictions in use of green belt land have forced better land use within the urban areas surrounded by green belt land (Morillas, JMB., Escobar, VG., Sierra, JAM., Gómez, RV. and Carmona J.T., 2002).

Due to a number of benefits of green belt policy, the government encourages local authorities to include green belt land in their developmental plans. The policy has not shown equally effective in all areas; however, the time has shown that green belt policy has more advantages than disadvantages especially when it comes to protection and improving quality of life for both rural and urban population (Gunnarsson AG, Ohrstrom E., 2007). Green belt policy may not work well in all areas and has been a subject of criticism in the recent years; however, its advantages by far outweigh its disadvantages (Mishra RK, Parida M. and Rangnekarınt S., 2010).

At this moment, green belt land covers about $13 \%$ of total area of Gulbarga City. Gulbarga District has 997.76 Sq kms means 6.15\% (269.26 Sq km is RESERVED, 230.50 PROTECTED AND 498.00 UNCLASSIFED FOREST) of the total geographical area is covered by forests making air quality and suitable wildlife habitat highly problematic. Green belts do not solve the problem related to low forest cover in the Karnataka but they significantly improve air quality and help combat a number of environmental problems (Aylor DE, 1972).

The Green Belt covers nearly2 \% of Gulbarga city, significant not only because of its extent, but because it provides both a breath of fresh air for the 8 lakh people living in or near to our largest towns and cities. Green Belt land faces many challenges. 
It is expected to meet diverse and often conflicting needs, and attracts considerable scrutiny due to the planning controls which govern it and the urban pressures which it faces (Rao, PS., Gavane, AG., Ankam, SS., Ansari, MF., Pandit, IV., and Nema, P., 2004). The original purpose of Green Belt is clear. It was introduced 60 years ago to protect the urban sprawl and to retain the character and vitality of cities. For this purpose, which remains fundamental, it has been highly effective.

Subsequently, objectives for the use of land once designated as Green Belt were introduced to planning policy (Krag, J., 1979). These were set to provide recreation and attractive landscapes, to improve damaged and derelict land, to secure nature conservation and to retain farming and forestry. Green Belt provides a rich and varied natural environment and many related benefits to society. The ecosystem services provided by Green Belt land are highly significant and have an economic value that is often underestimated or simply not understood (Pal A., Kumar V. and Saxena N., 2000).

\section{METHODLOGY}

Data collection is done through intensive survey with personal interviews and collection the public opinion. City population opinion is collected by supplying questionnaires. During the survey work a majority of Questions were asked during two weeks in July/August 2013 and Jan/Feb 2014 during the survey (43\%) of respondents both knew that Green Belts surround many major towns and cities, and valued Green Belts as places to enjoy quiet recreation, such as walking and cycling. Nevertheless, the debate about whether or not to retain Green Belt designation as a planning policy persists. The strengths and weaknesses of this long standing planning mechanism have been rehearsed in well publicized debate which has been driven by pressures to find sufficient land to satisfy housing targets.

Green belt development strategies emphasize the need for multi-functional use of land (Fang CF. and Ling DL, 2003), particularly in the face of climate change and population growth. 'Green infrastructure' within and around towns and cities has an important role to play. Green Belt is already making a contribution which could have even a greater significance in the future if it is managed effectively to maximize the benefits that a natural environment can deliver (Tyagi V., Kumar K. and Jain V., 2006).

The challenge is to find mechanisms and ways to invest in the land that realize its potential. This will involve working across public and private sectors, and across a range of disciplines.

\section{CONCLUSIONS}

1. It is inferred that Green Belt policy has been highly effective in achieving what it was intended to do despite considerable development pressures in the last half a century and is valid.

2. Green Belt has remained largely undeveloped, certainly compared to areas without Green Belt or other equivalent planning controls in place.

3. The positive role for Green Belt land was recognized by the Government. 
4. Green Belts have a role to play in achieving positive land use objectives.

5. It assesses whether more could be achieved to tackle the new challenges of climate change mitigation and adaptation and also climate change.

6. The concept of Green Belt also has strong support amongst the general public, even if they do not always understand the full details of the planning policy.

7. Green belt could take on an even greater significance in the face of climate change, Districts growing population and the need for a low carbon economy.

8. They can also help in creating a healthier society through providing space for active outdoor lifestyles and nutritious locally grown food.

9. Our request and ambition to enhance the benefits and services provided by Green Belt land so that we can be proud to pass it on to the next generation, and for all our major towns and cities to be surrounded by a recognizable and well maintained natural environment.

\section{References}

[1] Arana M., Garcia A., Applied Acoustics 53 (1998) 245-253.

[2] Aylor D.E., J. Acoust. Soc. Am. 51 (1972) 197-205.

[3] Cohen B., Technol Soc. 28 (2006) 63-80.

[4] Fang C.F., Ling D.L., Landscape and Urban Planning 63 (2003) 187-195.

[5] Fang C.F., Ling D.L., Landscape and Urban Planning 71(1) (2005) 29-34.

[6] Gunnarsson AG, Ohrstrom E., Landscape and Urban Planning 83 (2007) 115-126.

[7] http://nammagulbarga.com/ accessed 2013

[8] Krag J., Journal of Sound and Vibration 66(3) (1979) 407-415.

[9] Li B., Tao S., Dawson R.W., Applied Acoustics 63(10) (2002) 1137-1142.

[11] McMichael A.J., Bull World Health Organ 78(9) (2000) 1117-1126.

[12] McPherson E.G., Nowak D., Heisler G., Grimmond S., Souch C., Grant R., Rowntree R., Urban Ecosystems 1 (1997) 49-61.

[13] Mishra R.K., Parida M., Rangnekarınt S., J. Environ. Sci. Tech. 7 (4) (2010)737-750.

[14] Morillas J.M.B., Escobar V.G., Sierra J.A.M., Gómez R.V., Carmona J.T., Applied Acoustics 63(10) (2002) 1061-1070.

[15] Moudon A.V., Wee B.V., 2009. Environmental effects of urban traffic. In: Garling T, Steg L, editors. Threats from car traffic to the quality of urban life: problems, causes, and solutions. Amsterdam, Netherlands: Elsevier; 2007. p. 11-32.

[16] Pal A., Kumar V., Saxena N., Journal of Soundand Vibration 234 (2000) 149-165.

[17] Rao PS., Gavane A.G., Ankam S.S., Ansari M.F., Pandit I.V., Nema P., Ecological Engineering 23(2) (2004) 77-84. 
[18] Reethof G., Heisler G.M., 1976. Trees and forest for noise abatement and visual screening. USDA Forest Service General Technical Report, NE-22, pp. 39-48.

[19] Tyagi V., Kumar K., Jain V., Applied Acoustics 67 (2006) 926-935.

[20] Zannin P.H., Zanin F.B., Barbosa W. A., Applied Acoustic 63 (2002) 351-358. 